\title{
図書館員による洋書の海外直接発注
}

\section{Direct Acquisition of Foreign Books by Library Staff}

\author{
志 村 金 也* \\ 順天堂大学図書館
}

\section{I。はじめに}

$\lceil … . .$. 店頭で洋書を買う場合に，どのような為替レー トで買っているか, ためしてみることを锥めしたい。 そうすれば, 毎日, 新聞で見るレートと相当大きな差 があること，円が大幅に安く評価されていることに気 づくだろう。…今日，個人で外国の出版社から直接， 通常レートで本を買うことは容易である。それがいっ たん，洋書を大量に買う国立大学の研究室で買うとな ると，事務職員の手を借りた上に，值段も相当割高に なるというのは，何とも理解に苦しむことである。」 (文中傍点筆者)

少し長い引用になったが，これは東京新聞の「放射 線」というコラム闌（1985年10月11日付）に載った佐々 木毅氏（東大教授）の一文である。図書を購入するう えで, “事務職員”の介在が, 安価な図書購入にあまり 用をなしていないならば，事務職員は多いに反省しな ければならない。“事務職員”がすし図書館司書を指 すのであれば, 反省すべきは我々図書館員ということ になる。

佐々木教授のご指摘を待つまでむなく，このところ の異常な円高傾向下で洋書価格の換算レートに大きな 関心を持つユーザーが増えて来た。一方, 図書館業務 の中にコンピュータ・システムが導入されて以来, 図 書館員の役割は将来どのように变って行くのか，とい う検討がしばしば行なわれるようになった。図書館員 の将来像は，“端末のオペレーター”なのか，あるい は“事務職員”という専門性の希薄な職種なのか。い ずれにしても，むし，現段階でユーザーに“事務職員”

* Kinya SHIMURA : Juntendo University Library, 2-226 Hongo, Bunkyo-ku, Tokyo 113, Japan

(昭和61年 4 月 3 日 受理)
視されることを好まないならば, 洋書の購入に際して は，図書館員が介在すれば，ユーザーが直接発注する よりも適正な価格で，スムースに処理されるという印 象をユーザーに与えておく必要がある。

\section{II. 海外発注の具体例}

「図書館員による洋書の海外直接発注」という業務 のうち, 洋雑誌については，帝京大学による果敢な試 みが既になされている。1) そこで本稿では，単行本の 海外発注について，筆者の手元にある記録を開陳して 参考に供したい。（筆者が購入関連業務に携っていた 時期の関係で，時間的に古い記録であることをお許し 願いたい。)

$\lceil$ Systematized Nomenclature of Medicine」と いう洋書を参考図書として図書館に備付けて欲しいと いう依頼が研究室からあった。出入りの洋書取扱業者 から購入したが，図 1 がその時の納品書である。

その後, 同一書物を個人的に購入したいという要望 が 4 件図書館に寄せられた。購入希望者は，当然のこ とながら，できるだけ安価に，しかも早く入手するこ とを熱望したので, 個人購入の分については業者を通 さずに直接海外に発注した。発注から入荷までのプロ セスを箇条書きにすると下記の通りである。

1。価格を問合わす。（8月22日：図 2)

2 . 返事が来る。(9月 5 日：図 3 )

3. 返事に基づき, 銀行に出向いて「送金小切手」を 作成する。(9月6日：図4)

4.小切手を送付する。( 9 月 6 日 : 図 5 )

5。現物入荷（9月27日） 
以上, 価格の問合わせから着荷までの所要日数は航 空便で37日。所要金額は,

1。価格問合わせレター $¥ 120$

2. ドル小切手 $¥ 72,485(\$ 381.5 \times ¥ 190)$

3. ドル小切手作成手数料 $¥ 900$

4.ドル小切手郵送代 $¥ 420$ （書留航空郵便）

5。通関手数料 $¥ 100$ (着荷時に配達人に支払う)

$$
\text { 合 計 } ¥ 74,025
$$

（注 : 上記の金額は，いずれあ1978年 8 月時点のあの で, 1986年 4 月 2 日現在の数字は, ドル為替レート $¥ 176$ ，小切手作成手数料 $¥ 2300$, 書留航空便代 $¥ 500$ ）

結局，4 セット分の支払総額は $¥ 74,025$ であり，1人 1 セット分の負担額は $¥ 18,500$ であった。書店経由で 購入した図書館分 $¥ 32,200$ に比較すると，かなり安価 な出費で済んだことになる。

この例で分かるように, 海外への直接発注で難しい ことはなにもない。しかし，送金はしたけれど物が届
かないという事故が全くない訳ではない。そのような 事故を防ぐためには，1。送金前に郵送料などを含ん だ正確な価格を入手する。2，送金などレターのやり とりには，必らずレファレンス・ナンバーを明記する こと,の 2 点が大切であると思う。

\section{III. 直接発注の問題点}

適正レートで洋書を購入できるからといって，むや みに直接発注する訳にもいかない。理由は，前記帝京 大学医学図書館の報告例にもあるように,

1. 小切手作成，クレーム処理など事務量が増える。

2. 低額図書では, 送料・手数料などで割高になる。

3。代理店以外からの個別注文には応じない出版社や 出版物がかなりある。

4. 前払いであるための, 会計上の問題点。 などなど。

結局, 図書館員による直接発注適応のケースとして は, (1)高額なもので, (2)商業ベースに乗らない学協会・

(3) 納品輩 №. 4065195

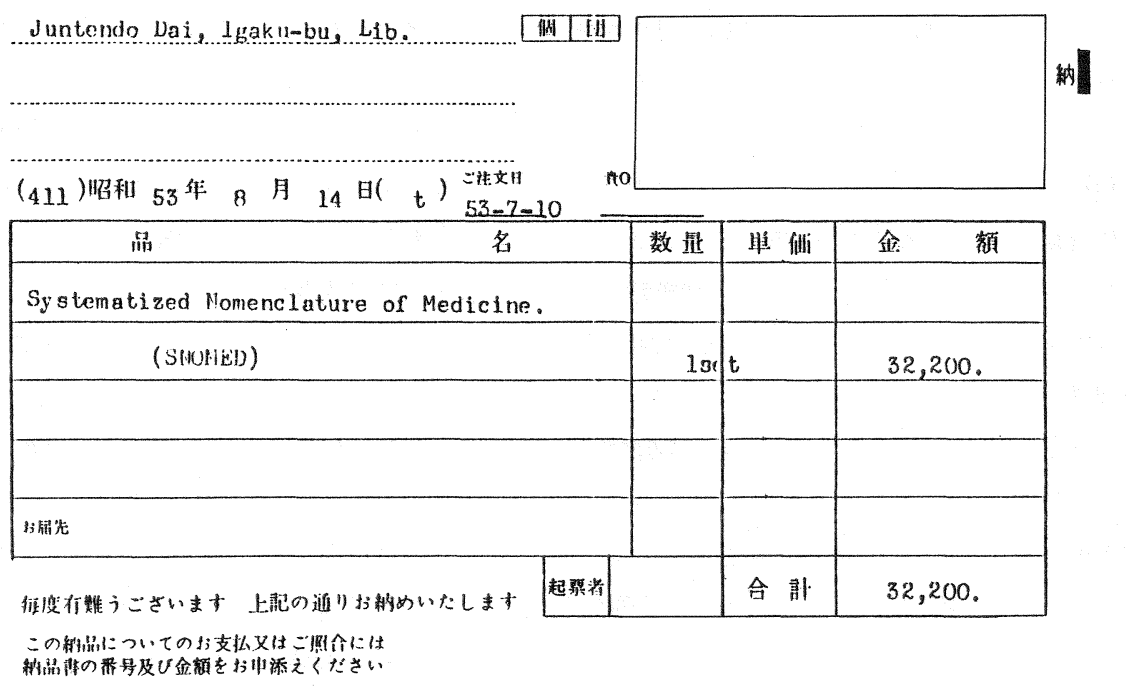




\section{JUNTENDO UNIVERSITY \\ SCHOOL OF MEDICINE \\ HONGO, TOKYO}

College of American Pathologists

7400 North Skokie Blvd.

Skokie, I11. 60076

USA

August 22, 1978

Subject: SNOMED (Systematized Nomenclature of Medicine)

Dear Sirs,

We understand you have published the captioned tites, and we'd like to obtain 4 sets of them.

As we are in a hurry to get them, we wish to be sent them via airmail.

Please send your pro-forma invoice covering the price for 4 sets and airmail postage as quickly as possible.

Thanking you in advance for your prompt reaction on this matter and looking forward to hearing from you soon.

図 2. 価格の問合せ 
店 COLLEGE OF AMERICAN PATHOLOGISTS

-4OO NOATHA SKMKIE BOI!LVAFO

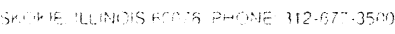

k. Shimura

Library

Juntendo Univ.

$2-2-26$ Hongo

Bunkyo-ku, Tokyo 113

Japan

Dear Customer,

This letter pertains to your order \# letter, which is attached, requesting 4 copy(ies) of our publication entitled: snomed - We are sorry to

have to return your order to you, but it is a policy of the College to have all orders outside of the U.S. and Canada prepaid.

Cost of Publication:

$\$ 280.00$

Add Air Mail printed Matter Charge $\$ 101.50$

Other (Air Freight, etc.) Specify: \$

$$
\text { TOTAL } 381.50
$$

Please RETURN YOUR ORIGINAL ORDER with your check. Allow 6-8 weeks for delivery.

(You may elect to send the publications by surface mail for a charge of $\$ 13,50$, We can not be responsible if you do not receive the publications as this method is very slow and undependable. You should allow 4 months for delivery via this method.) $\therefore$ TOTAAL $\$ 293.50$

Thank you for your cooperation. If you have any questions, please do not hesitate to contact this office for assistance.

Kathleen Kotara

Publications Order Department

図 3. 価格の通知 (Proforma Invoice) 


\section{THE KYOWA BANK, LIMITED}

Chiyoda-ku, Tokyo, Japan

Sept. 6,1978 OUR NO. DD 961130688 MONTH DAY YEAR

PAY AGAINST THIS CHECK

TO THE ORDER OF COJTEGE OF AMTRTCAN PATHOTIOTTSTS

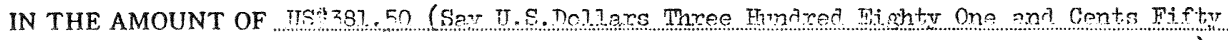

図 4。送金小金手

Publication Order Denartment

COI,LEGE OF AMERICAN PATHOLOGISTS

$7400 \mathrm{~N}$. Stroke Blvd

Skokie, I11. 60076

U S A

Dear Sirs,

We are enclosing herewith a bank check for US\$381.50 corresponding your letter(encls).

Please send the materials at your earliest convenience by parcel post via airmail.

Thank you for your cooperation.

Enc1:1. Bank Check no.:DD96113068r

2. Your acknowledgment

3. Our original order 


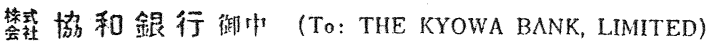

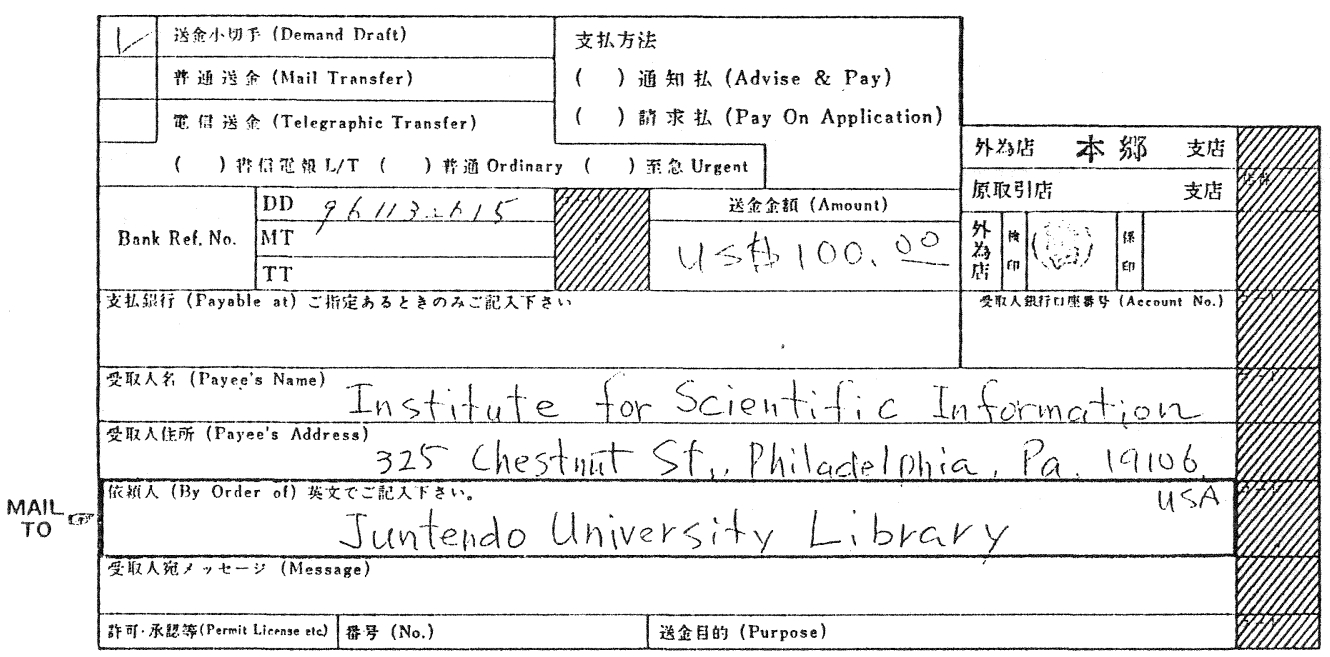

上歡送金を打取扱致しました。

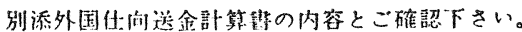

缹篗協和銀行

(THE KYOWA BANK, LTD.)

国存 5 年 (外为 367 A) $3 / 5 \quad 51.7$

THE KYOWA BANK, LIMITED

Chiyoda-ku, Tokyo, Japan

PAY AGAINST THIS CHECK

TO THE ORDER OF

Institute for Soinntific Information

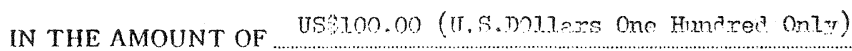
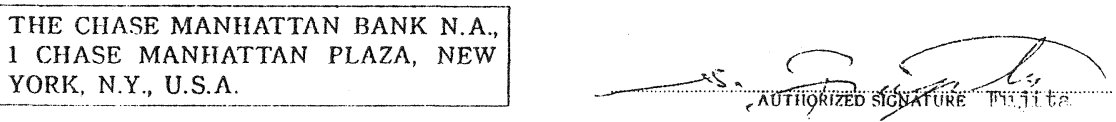

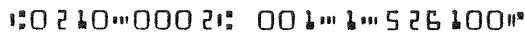


政府刊行物の場合と考えることができる。

例えば，1986年版 Index Medicus(月刊)の国内力 タログ・プライスは $¥ 66,400$ であるが，定価は $\$ 193.75$ である。先に述べたやり方で海外発注すると，直接コ スト $(\$ 193.75 \times ¥ 176=¥ 34,100)$ と雑費 $(¥ 2,800)$ の 合計 $¥ 36,900$ で入手できる。IM の場合は，日本の大 蔵省印刷局にあたる所謂 GPO (Superintendent of Documents, U.S. Government Printing Office) から入手できて, 海外向け価格むキチンと設定されて いるので，価格の問合わせは省略してもよい。

1986 Current Contents（Life Sciences）の国内

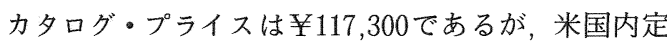

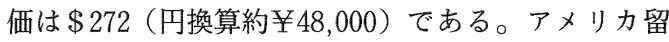
学中に購読していた研究者が, 日本に帰国して改めて 購読しょうとすれば，あまりの差額に目をむくかもし れない。いくら目をむ加ても, Institute for Scientific Information の出版物は直接発注できない。ユ サコと紀伊国屋が日本国内での独占販売権を持ってい るので, 日本からの発注はそちらへ回送されてしまう からだ。ISI では，著者に直接論文請求するための既 成ハガキ（Request-A-Print）を販売していて， 1978年当時1000枚 \$100のものが，国内価格 $¥ 35,000$ であった。筆者は直接発注によって 2 万円足らずの費
用（図6）で入手したが，現在は独占販売権が設定さ れているのでユサコか紀伊国屋から1000枚 $¥ 59,500$ （米国内定価 \$160）で購入することになる。

\section{IV.むすび}

巷間，医師という職業は金回りがよいとの認識があ る。従って医科系大学の図書予算も豊富な筈であると 考えている書店もあるようだ。従来の洋書取扱い業者 とは異なる方法で洋書を納入する業者が医科系大学に あ参入して来ている。いわゆる平行輸入による洋書の 入手む行なわれているようで，既在の大手業者む最近 では輸入洋書の円価設定にはそれなりの神経は使って いるようだ。結局，ひとしく厳しい予算状況下にある 我々医科大学の図書館員としては, 洋書の購入にあたっ ては，適書の選択と同時に適所からの入手にも配慮す ベきであると思う。

\section{参 考 文 献}

1 ) 小川邦弘 ほ力: 帝京大学医学図書館の外国雑誌 購入について。医学図書館, 32 (2) : 147-158, 1985 . 